\title{
The Second International African-Caribbean Cancer Consortium for the study of viral, genetic and environmental cancer risk factors Camille Ragin*1,2,3 and Emanuela Taioli1,2,3
}

\author{
Address: ${ }^{1}$ Department of Epidemiology, University of Pittsburgh Graduate School of Public Health, PA, USA, ${ }^{2}$ The University of Pittsburgh Cancer \\ Institute, Pittsburgh, PA, USA and ${ }^{3}$ Department of Epidemiology and Biostatistics, Downstate School of Public Health, State University of New \\ York, USA \\ Email: Camille Ragin* - Camille.Ragin@downstate.edu ; Emanuela Taioli - emanuela.taioli@downstate.edu \\ * Corresponding author
}

from Second Annual International African-Caribbean Cancer Consortium Conference

Miami, FL, USA. 12-13 May 2008

Published: 10 February 2009

Infectious Agents and Cancer 2009, 4(SuppI I):SI doi:I0.II86/I750-9378-4-SI-SI

This article is available from: http://www.infectagentscancer.com/content/4/SI/SI

(C) 2009 Ragin and Taioli; licensee BioMed Central Ltd.

This is an open access article distributed under the terms of the Creative Commons Attribution License (http://creativecommons.org/licenses/by/2.0), which permits unrestricted use, distribution, and reproduction in any medium, provided the original work is properly cited.

\section{Introduction}

The Second International Conference of the African-Caribbean Cancer Consortium (AC3) was held on May 1213, 2008 at the Wyndham Miami Airport Hotel \& Executive Meeting Center in Miami, FL, USA. The conference was organized by the University of Pittsburgh, Graduate School of Public Health and the University of Pittsburgh Cancer Institute.

The AC3 (http://www.ac-ca-consortium.org) was established in 2006 for the study of viral, genetic, environmen$\mathrm{tal}$, and lifestyle risk factors for cancer in populations of African descent [1]. The goals of this year's conference were to provide a forum for the Consortium members to (1) share their research accomplishments (2) Identify areas for further study and (3) build new collaborations. There were 38 attendees that represented institutions from various countries: The Bahamas; Barbados; Guyana; Jamaica; Nigeria, Africa; Trinidad and Tobago; and the United States (US). The attendees had an opportunity to present their research either through oral or poster presentations. Networking and further discussions were facilitated by question and answer periods after each presentation as well as during the session breaks and dinner reception.

\section{May 12, 2008}

The conference began with the welcome and opening presentation by Dr. Camille Ragin, the principal investigator of the AC3, who defined the AC3's purpose, goals, and provided a brief overview of the membership status as well as a summary of the ongoing AC3 research studies. Currently there are 53 AC3 members many of whom are conducting collaborative studies of cancer risk among individuals of African descent. The AC3 is conducting collaborative studies on the etiology of cervical cancer in the Bahamas, Tobago, Jamaica and US while studies in Guyana and Nigeria are planned. Prostate cancer collaborations have been established in the Bahamas, Jamaica, Nigeria and US. Other collaborative studies that assess cancer prevalence, screening, knowledge and perception have also been established or are planned in Guyana, St. Kitts/Nevis, St. Vincent, US Virgin Islands and the US.

\section{Session I: Prostate Cancer and HHV8 Infections in Populations of African Descent}

This first general session was chaired by Dr. Clareann Bunker from the University of Pittsburgh, US and Dr. Robin Roberts from the University of the West Indies, the Bahamas. The session was lead by a keynote presentation by Dr. Folakemi Odedina of Florida A\&M University, US, entitled "Tracing the Root of Prostate Cancer Disparities in Black Men: From West Africa to Caribbean Islands to 
United Kingdom". Dr. Odedina provided a brief history of the Transatlantic Slave Trade, described how various populations of African descent were connected worldwide. She described the current status of prostate cancer research in these populations, highlighting the limited knowledge of prostate cancer burden in West African populations as well as few research studies in African-Caribbean populations. The presentation ended with a charge that corresponds with the primary goal of the AC3 project. In order to address the prostate cancer disparity in Black men, collaborative studies with standardized methods and protocols are needed in order to explore prostate cancer burden and its risk factors among men of African ancestral origin (African-Caribbean, African-American and African). Session I continued with five additional short presentations of research findings by AC3 members [2-6].

\section{Session II: Cervical and Other HPV-Associated Cancers in Populations of African Descent}

The second general session was chaired by Dr. Camille Ragin from the University of Pittsburgh, US and Dr. Norma McFarlane-Anderson from the University of the West Indies, Jamaica. The keynote address was given by Dr. Raleigh Butler from the University of the West Indies, The Bahamas and was entitled: "Fact, Frictions and Fractions, HPV the Bahamian Experience". Dr. Butler presented an overview of the Epidemiology of HPV and related cancers and described the current status of this disease among Caribbean populations. Cervical cancer is the second cause of cancer deaths in the Bahamas, and annual cervical screening is performed in less than $10 \%$ of this at risk population. Session II continued with four additional presentations of human papillomavirus (HPV) related studies conducted in Caribbean populations [7-10].

Day one of this conference concluded with two Special Topics sessions. The first, "Sample Collection, Data Sharing and Confidentiality" was facilitated by Dr. Emanuela Taioli from the University of Pittsburgh. The participants defined appropriate protocols for collection and storage of data and samples as well discussed the importance of standardization in multi-centered collaborative studies. The second Special Topic, "Building Infrastructure for Multi-Center Studies" was facilitated by Dr. Judith Jacobson from Columbia University. During this session the participants discussed decisions and steps necessary for obtaining funding and implementing a collaborative study.

The day ended with a dynamic poster session and networking dinner reception, where the participants continued their discussions about their research projects and reconnected with their colleagues and met new ones.

\section{May 13, 2008}

Session I: Breast Cancer in Populations of African Descent This session was chaired by Dr. Michael Okobia, from the University of Benin, Nigeria and Dr. Emanuela Taioli from the University of Pittsburgh, US. Dr. Taioli launched the session as the keynote speaker where she presented the descriptive Epidemiology of Breast cancer among individuals of African ancestry; discussed risk factors for this disease and identified the gaps in research for minority populations. Dr. Taioli also presented some of her current research findings from her studies of African American populations. The session ended with three additional research presentations by AC3 investigators [11-13].

The breast cancer session was followed by a Special Topic discussion on Cancer Registration. There were presentations of cancer statistics by Ms. Veronica Roach from Dr. Elizabeth Quamina Cancer Registry in Trinidad and Tobago and Dr. Wallis Best-Plummer representing the Guyana Cancer Registry in Guyana. The presenters provided data from their corresponding cancer registry and were later joined by Dr. Michael Okobia, from the University of Benin, Nigeria for a panel discussion about the establishment process of cancer registries and the challenges surrounding cancer registration in developing countries.

The conference concluded with concurrent breakout sessions where AC3 investigators divided into cancer-specific working groups (cervical, breast and prostate). During these sessions, AC3 investigators discussed the status of the ongoing collaborative studies and defined future studies.

\section{Conference evaluations}

All participants were asked to complete evaluation forms for both meeting dates and $95 \%$ of the forms were returned. The majority of the participants $(65 \%)$ reported that, based on their prior knowledge, they learned more after attending the cancer registration session. In general, participants reported that the conference fulfilled their reason for attending $(73 \%)$. Eight-five percent were satisfied with the conference content, organization (81\%), and overall conference experience (85\%).

\section{Competing interests}

The authors declare that they have no competing interests.

\section{Acknowledgements}

This conference was supported in part by funds from the University of Pittsburgh, Graduate School of Public Health, Dean's office and the University of Pittsburgh Cancer Institute and grant number RI3CAI30596A to CR and P20CAI32385-0I to ET. This project was also made possible by Grant Number KL2 RR024I54-03 from the National Center for Research Resources (NCRR) [14], a component of the National Institutes of Health (NIH), and NIH Roadmap for Medical Research [15]. Its contents are solely the responsibility of the authors and do not necessarily represent the offi- 
cial view of NCRR or NIH. Thanks to our sponsor Roche Diagnostics for their generous support of this meeting.

We would like to personally thank and acknowledge Dr. Donald Burke, Dean of the University of Pittsburgh Graduate School of Public Health and Dr. Ronald Herberman, Director of the University of Pittsburgh Cancer Institute for their support of this conference.

This article has been published as part of Infectious Agents and Cancer. Volume 4 Supplement I, 2009: Second Annual International African-Caribbean Cancer Consortium Conference. The full contents of the supplement are available online at http://www.infectagentscancer.com/supplements/4/SI.

\section{References}

I. Ragin CC, Taioli E, McFarlane-Anderson N, Avery G, Bennett F, Bovell-Benjamin A, et al.: African-Caribbean cancer consortium for the study of viral, genetic and environmental cancer risk factors. Infect Agent Cancer 2007, 2:17.

2. Consedine N, Christie M, Neugut A: Physician, Affective, and Cognitive Variables Differentially Predict "Initiation" versus "Maintenance" PSA Screening Profiles in Groups of Caribbean Men. [abstract]. Second International African-Caribbean Cancer Consortium Conference, May I2-13, Miami FL 2008:abstract I.

3. Jackson M, Walker S, Simpson C, McFarlane-Anderson N, Bennett F, Coard M, et al: Are food patterns associated with prostate cancer in Jamaican men: A preliminary report. Infect Agent Cancer 2009:S5.

4. Reams R, Agrawal D, Davis M, Yoder S, Higginbotham J, Odedina F, et al: MicroArray analysis uncovers differential gene expression in prostate tumors between African-American and caucasian American men. Infect Agent Cancer 2009:S3.

5. Roberts R: Surgical versus medical castration in the Bahamas: a male macho paradox. Infect Agent Cancer 2009:S4.

6. Ukoli F, Taher K, Akumabor P, Osime U, Beech D: The role of meat, fish, and egg intake in prostate cancer risk among Nigerians. Infect Agent Cancer 2009:S6.

7. Best Plummer W, Persaud P, Layne P: Common cancers of the Afro-Guyanese population: a silent issue for too long. Infect Agent Cancer 2009:S7.

8. Dames D, Ragin C, Griffith-Bowe A, Gomez P, Butler R: The prevalence of cervical cytology abnormalities and human papillomavirus in women infected with the human immunodeficiency virus. Infect Agent Cancer 2009:S8.

9. McFarlane-Anderson N, Bazuaye P, Jackson M, Smikle M, Fletcher $\mathrm{H}$ : Hormonal contraceptive use in Jamaican women: is there an association with cervical lesions? [abstract]. Second International African-Caribbean Cancer Consortium Conference, May 12-13, Miami FL 2008:abstract 5.

10. Ragin C, Watt A, Markovic N, Buker C, Edwards R, Eckstein S, et al:: Comparison of type-specific distribution of HPV infections in populations of African descent. Infect Agent Cancer 2009:S9.

II. Grann V, Bowman N, Joseph C, Wei Y, Horwitz M, Jacobson J, et al: Neutropenia in Six Ethnic Groups from the Caribbean and the United States. [abstract]. Second International African-Caribbean Cancer Consortium Conference, May 12-13, Miami FL 2008:abstract 5.

12. Hennis A, Hambleton I, Nemesure B, Wu S, Leske M: Breast cancer incidence and mortality in Barbados, West Indies. [abstract]. Second International African-Caribbean Cancer Consortium Conference, May 12-13, Miami FL 2008:abstract 3.

13. Okobia M, Buker C, Garte S, Zmuda J, Ezeome E, Anyanwu S, et al.: Leptin receptor GIn223Arg polymorphism and breast cancer risk in Nigerian women: A case control study. Infect Agent Cancer 2009:SI2.

14. National Institutes of Health: 2007 [http://www.ncrr.nih.gov/]. National Institutes of Health, National Center for Research Resources

15. NIH Roadmap for Medical Research: 2007 [http://nihroad map.nih.gov/clinicalresearch/overview-translational.asp]. NIH Roadmap for Medical Research, Re-engineering the Clinical Research Enterprise Publish with BioMed Central and every
scientist can read your work free of charge

"BioMed Central will be the most significant development for disseminating the results of biomedical research in our lifetime."

Sir Paul Nurse, Cancer Research UK

Your research papers will be:

- available free of charge to the entire biomedical community

- peer reviewed and published immediately upon acceptance

- cited in PubMed and archived on PubMed Central

- yours - you keep the copyright

Submit your manuscript here:

http://www.biomedcentral.com/info/publishing_adv.asp
BioMedcentral 